\title{
Speaking Performance and Anxiety: A Correlation Study in EFL Senior High School Students in Madiun, East Java
}

\author{
${ }^{1}$ Samsul Arifin, ${ }^{2}$ Thoriq Rizki Firis Manda* \\ Universitas PGRI Madiun \\ *Corresponding Author \\ Email: samsul0442@gmail.co.id
}

\begin{abstract}
This research is conducted to see if there is a significant correlation among the students' speaking performance and speaking anxiety of eleventh grade students in Madiun, East Java. There were 22 students who participated in this study. The researcher used quantitative research method with correlational research design. The researcher collected the students' speaking performance through the speaking test using Brown's speaking assessment and investigated their speaking anxiety using 1-5 Likert-scale questionnaires. The questionnaires were modified from students' speaking anxiety scale conducted by Woodrow. The data were analyzed using IBM SPSS (Statistical Package for the Social Science) ver 22, specifically on normality and correlation test. The result shows that the correlation coefficient number of -0.766 and sig (2-tailed) at 0.000. It means that the $\mathrm{HO}$ is rejected and $\mathrm{Ha}$ is accepted, and there is a significant correlation among two variables, moreover the two variables are strongly negative correlated.
\end{abstract}

Keywords: Speaking performance, speaking anxiety, English as a foreign language

\section{INTRODUCTION}

Spoken language is an important aspect for human in social life especially communication. The spoken language is the most common form of language to be used in daily communication. When people are communicating directly, the basic form of language used is spoken language. Spoken language which is called as conversation has social function that is to reduce personal distance or to establish a good relation among two people. Richards (2008) asserts that people speak to exchange greetings, small talk, experiences and another message with the other to create comfortable zone. To be able to reach the goal, it is important to master the indicators of speaking skills and to learn how to speak fluently and accurately. Harmer (2001) says that speaking is the ability to speak fluently and presupposes not only knowledge of language features but also the ability to process any information and language on the spot. The skills involves producing sounds from the processing of data received.

Speaking skill is an essential skill to be mastered by people because by mastering speaking they can deliever their ideas to others. Exchanging information in a good and proper way is also the benefit of mastering speaking skill. Rao (2019) asserts that speaking skill development is not only significant in helping effective communication in English as the second language but it also helps in building an effective communication so that the students may be able to achieve their goals on communication. Speaking skill activities help students to improve their 
comunication ability which is can be seen from the product of speaking skill lessons, that is speaking performance.

For English Foreign Language (EFL) learners, mastering speaking is a must. They use speaking for presenting their works in front of the class, when the teacher conducts group discussion, when they are asked to give a speech in a competition, and the others. To show their mastery to the language skills during the teaching learning process, the students must be able to perform it well. This is in line with Richards (2008) which states that the success of English learner is the development of their speaking performance in accordance with the effectiveness of their English course. The effectiveness of the lesson relates to the method, approach, media and the theacher who gives the materials. The method, approach, and media underlying the process of teaching speaking can be both arising and decreasing the students speaking performance and motivation. In addition, the teachers performance can also effect the same as methods of which later it can bring negative perception that speaking skill is difficult to master.

Speaking skill is the hardest skill to be mastered by the students. Study by Oradee (2012) which investigates the students' attitude towards speaking class, stated that the most essential skill is speaking and it is the hardest skill to be mastered as well. Rao (2019) said that when speaking skill is the hardest skill to be mastered but speaking skill also become one of important macro skill to be mastered. It can be said that speaking is an important skill to be mastered by the English language learners because it is the hardest skill and it will help them to communicate better, thus English is taught in every level of education. According to Adriana and friends (2014) speaking English skill is hard. It is one of the most challenging skills to be practiced by the students. In this case the students are not only taught to speak in the class but also outside of the class, in extraculicular activities, for example. In sum, it can be understood that the students are having speaking anxiety.

Research investigating speaking and anxiety was conducted, these researches also reveal the solutions to decrease the students' speaking anxiety. One of the researches conducted by Young (1990) finds that the students more likely to be anxious when they are asked to speak in front of their friends. She also states that their anxiety is decreased when they are asked to speak in pairs or in a group discussion. Therefore speaking activity should be brought together with the other activities such as discussion rather than only conducting monologues. The other research done by Tsiplakides (2009) results on the conclusion that the students are having speaking anxiety and why the students experiencing it. Besides, he also notes that the speaking anxiety can be reduced by using project work, building supportive atmosphere in the class, establishing a good relation among the students and the teacher, avoiding direct correction, keeping the students' confidence, paying attention on teachers' attitude towards the students and praising the student. Those solution may solve the problem of speaking anxiety in the class. The speaking anxiety of the students is really exist when they are asked to speak, especially in english, however there are solution to solve the problem from the other researcher.

Some research finds solutions to reduce the students speaking anxiety. The research conducted by Anderson et al. (2005) found that the Speaking Anxiety or in that research it is called as Fear of Public Speaking (FOPS) can be decreased by 
the use of Cognitive Bhevioral Therapy (CBT) using Virtual Reality (VR). He found that the use of CBT and VR is effective to reduce FOPS. While research by Chou (2018) results into the solution to face students' speaking anxiety, that is by using full English Medium Instruction (EMI). EMI is a way of teaching which is used to teach subjects in non-native English speaker, in Chou's research context, it is Taiwan. It shows the result that the students who received full-EMI have decreased their speaking anxiety. In sum the researches establish related to speaking anxiety generally talk about solutions to minimize the students' speaking anxiety especially to minimize the speaking anxiety of EFL students in the class.

Speaking anxiety exists as the problem of non-native college students in Australia. The previous research conducted by Woodrow (2015) in Australia which concern on the anxiety faced by non-native students in English speaking country (Australia). The researcher found that the second language anxiety which measured by the scale of the second language speaking anxiety is relevant to English students studying in Australia universities. Woodrow provides new instrument to measure second language speaking anxiety which will be adapted in this research. Using the instrument she claims that the speaking anxiety of Australia English students has a negative correlation with their speaking performance.

From research above, the researcher is interested in investigating more about the correlation of the students' speaking anxiety and their speaking performance. Since the previous research was investigating the university students, in this research the researcher investigates the correlation of speaking anxiety and speaking performance of eleventh grade students.

\section{Students' speaking anxiety}

Anxiety occurs when a person think that something goes not really well. Anxiety is a common thing for human. Rector, n.d. (2005) said that the data shows that one from four people are having an anxiety, whether it happened in the present and in the past. They also asserts that anxiety affects human in some aspects. First, cognitive, anxiety affects on the person's thinking, it may cause a person become overthink of a problem. Then, physical, include heart palpitations or increased heart rate, shallow breathing, trembling or shaking, sweating, dizziness or lightheadedness, feeling "weak in the knees," freezing, muscle tension, shortness of breath and nausea. The last, behavioral, the person will take a self-defense such as avoiding. As stated that anxiety happened while a person is scared that something bad will happen then he/she shows some symtomps and it is happen to anyone, it means, including students.

The anxiety of the students can be seen from some attitudes which showed by them. As Goberman, Hughes, \& Haydock (2011) find in their study, there are some differences on acoustic characteristic and voice production can be seen as the effect of anxiety on speaking performance.

1. The change of articulation rate. In the two speeches, the articulation rate of the performer is higher in the second speech rather than the first one. The factor affected this, related to anxiety is the time. In the second speech, the students feel more pressed by the obligation to end their speech on time moreover, their second speech contains more information.

2. The change of disfluency in the beginning and in the middle to end part of the speech such as the repetition of words, blocks, prolongation, and interjection 
(fillers, like "um", "ah") which shows their uncertainty about the meaning or the pronunciation of the words.

3. The change of Fundamental Frequency of Standard Deviation FoSD between the first speech and the second speech. The first speech has the higher FoSD rather than the second. It indicates that the students is more having anxiety in the first speech, when they start. Then they find the comfortable state in the ending.

\section{METHOD}

\section{Research design and respondents}

The research was conducted in MAN 2 Kota Madiun and it was done in seven months. It started on December 2019 to June 2020. In this research, the researcher was using quantitative approach. The design of this study was Correlational Study. The population of this research was the eleventh grade students of senior high school in Kota Madiun, East Java. The total of the eleventh grade students was more than 400. The eleventh grade students were chosen because the researcher believe that they are already mature enough. Mature in the terms of age and psychology which affect to the self-responsibility to do their role in this research. Second, they already had enough knowledge, especially in speaking skill so that when they are asked to perform their speaking skill, they are ready whether in the vocabulary, pronunciation and grammar. The sample of this study was the students of eleventh grade in XI MIA 4 which contains 36 students, 15 male students and 21 female students and XI MIA 5 which contains 36 students, 14 male students and 22 female students. The researcher was using simple random sampling technique in order to make the study more effective. This method is choosen because the researcher wants to give the population chance to be chosen. The researcher made the lots of 12 classes of eleventh graders in Kota Madiun then draw two classes to be the sample. There were two ways to draw the lots. Those ways were, first, drawing without returning the lot taken, second, by returning the lot taken. However in this research the researcher return the lot taken into the scond draw so the probability of the lots to be taken is still the same.

\section{Technique of collecting data and instrument}

The technique used in this study is test and questionnaire filling. The test is extensive speaking. This speaking form is a complex, relatively lengthy stretches of discourse. Variations on monologues, usually with minimal verbal interaction are found in this speaking form (Brown, 2004). The test was done by the students by turns. The test was speaking test in a certain materials which is taught in the time of research. The students performed a monologue speech with certain topic in front of the class. Their performance was assessed with the speaking performance assessment table by Brown (2004) consisting the aspects of grammar, vocabulary, comprehension, fluency, pronunciation, and task. The questionnaires to measure the students' anxiety on speaking was modified from Woodrow (2015). Her research focused on speaking anxiety of the student while they are having a conversation with natives. However the researcher made some adjustment to the questionnaires. The questionnaries contained twelve points. Each point explains a situation faced by the students. The situations were such as their anxiety on facing speaking test, having interaction with teacher and the problems around that topic. 
For each point there are five range of anxiety. The students should read the points carefully and circle the 1-5 numbers Likert scale in anxiety coloumn based on the anxiety they feel in that situation.

\section{Technique of data analysis}

The data gained from the research were analyzed by computer statistic data analyzer, SPSS (Statistical Package for the Social Science) Version 22. This data analyzer application was used because this application has a very versatile data processing capability. Normality test conducted to see if the data gained from the study are normally distributed, in this case the data of peaking test. The normality test used Shapiro-Wilk test. Pearson Correlation was used to measure the strength and direction of the linear relationship of two variables.

\section{RESULTS AND DISCUSSION}

\section{Hypothesis testing}

In this section, the researcher shows the result of data processing. The data processing result answers the research question, whether there is a correlation among students' speaking performance and their speaking anxiety. The data processing shown in this part is Normality test and Pearson correlation. These processes were using SPSS ver 22.

\section{Normality test}

The normality test used in this research is Saphiro-Wilk test since the number of the sample is under fifty $(<50)$. The sample (n) of this research is 22 . The analysis of the normality is below.

Table 1. Normality Test

\begin{tabular}{|c|c|c|c|c|}
\hline & \multirow{2}{*}{$\begin{array}{c}\text { Speaking } \\
\text { Anxiety }\end{array}$} & \multicolumn{3}{|c|}{ Shapiro-Wilk } \\
\cline { 3 - 5 } & 58.33 & & & Statistic \\
Speaking & 65.00 & & & \\
\cline { 2 - 5 } Score & 70.00 & .980 & 3 & .726 \\
\cline { 2 - 5 } & 76.67 & & & \\
\hline
\end{tabular}

From the table above, it can be seen that the sig. number is 0.726 . As stated before that the data is normally distributed ( $\mathrm{H} 0$ is accepted) when the sig is $\geq 0.05$ while they are not normally distributed ( $\mathrm{H} 0$ is rejected) when the sig value is $\leq 0,05$. The number of $\operatorname{sig}(0.726)$ is $\geq 0.05$ then it can be said that the $\mathrm{H} 0$ is accepted or the data are normally distributed.

\section{Pearson Correlation}

The data gained in this research are analyzed in SPSS ver 22 to see whether is there any correlation among the students' speaking performance and their speaking anxiety. The analysis of the Pearson correlation can be seen in the following table.

Table 2. Pearson Correlation

\begin{tabular}{|c|c|c|c|}
\hline & & Speaking Anxiety & Speaking Score \\
\hline \multirow{3}{*}{$\begin{array}{c}\text { Speaking } \\
\text { Anxiety }\end{array}$} & Pearson Correlation & 1 & $-.766^{* *}$ \\
\hline & Sig. (2-tailed) & & .000 \\
\hline & $\mathbf{N}$ & 22 & 22 \\
\hline \multirow{3}{*}{$\begin{array}{c}\text { Speaking } \\
\text { Score }\end{array}$} & Pearson Correlation & $-.766^{* *}$ & 1 \\
\hline & Sig. (2-tailed) & .000 & \\
\hline & $\mathbf{N}$ & 22 & 22 \\
\hline
\end{tabular}


In table 2. the number of the sample (n) is 22. The result of speaking score and speaking anxiety calculation are analyzed using Pearson Correlation and result on that table. It can be seen that the coefficient correlation is -0.766 and the significance value, sig. (2-tailed) is 0.000 . Those values reveal the correlation among both variables, The students' speaking performance and their speaking anxiety.

The significance of the correlation can be seen from the value of Sig. (2tailed) and the coefficient correlation ( $\mathrm{r}$ count). When the value of Sig. (2-tailed) less than 0.05 , it means there is a significant correlation among two variables. When the value is more than 0.05 , it means there is no significant correlation. The value of Sig. (2-tailed) of this research is 0.000 . That value $(0.000)$ is less than 0.05 , or it can be written as Sig. (2-tailed) $<0.05$. The $r$ count of this research is 0.766 , meanwhile, the $r$ table of $\mathrm{N}=22(\mathrm{df}=\mathrm{N}-2)$ in bivariate test is 0.4227 . The $\mathrm{r}$ count, $0.766>r$ table, 0.4277 . When $r$ count is bigger than $r$ count it means the variables are significantly correlated. From the explanation above it can be seen that there is a significant correlation among two variables, the students' speaking performance and their speaking anxiety.

The value of coefficient correlation in the table, -0.766 shows the kind and the strength of the correlation. There are two kinds of correlation, those are positive and negative correlation. The positive correlation can be seen when the coefficient correlation has positive value, or it is between 0 until +1 and the negative correlation is shown by the negative value or when the value is between -1 until 0 . This research result is in negative value, it means the correlation of both variables is negative correlation. While the number of the value shows the strength of the correlation. When the number is between 0.1 until 0.3 it means the correlation is weak, 0.3 until 0.5 shows the moderate correlation, and when the value is more than 0.5 it means the correlation is strong. The coefficient correlation of this research is 0.766 , it is more than 0.5 it means the strength of the correlation is strong. In sum, the value of coefficient correlation, -0.766 shows that the two variables are strongly negative correlated.

To ensure the result of analysis above, the researcher uses the another way. The another way to check the correlation of two variables scatter plot can be used. There are three kinds of data spread in scatter plots and each data spread has its own meaning. For example, when a line can be drawn along the data spread from bottom left to the top right, it can be concluded that those two variables are positively correlated. When the data are randomly spreaded, it meas there is no correlation. The third kind, when the line is from top left to the bottom right, it means the two variables are negatively correlated. Recent study shows the third kind of scatter plot so the variables in this study are negatively correlated. The scatter plot can be seen below.

Figure 1. Scatter plot

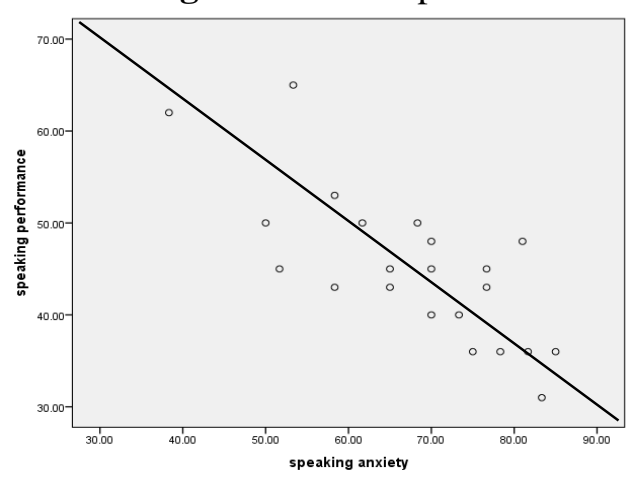


The result of both analysis, the analysis of Pearson correlation test and the scatter plot shows that there is a significant correlation among two variables. The correlation is negative correlation because the value of coefficient correlation is negative and the scatter plot is from top left to the bottom right. Moreover, the value of coefficient correlation is 0.766 , it is more than 0.5 , then it can be understood that they are strongly related.

\section{Discussion}

This part discusses the result of the research. The data analysis shows that the $\mathrm{Ha}$ in this research is accepted. There is a significant correlation among two variables. It can be proved by the value of Sig (2-tailed) of Pearson correlation analysis in SPSS ver 22 in this research. The Sig (2-tailed) value is 0.000 which is smaller than 0.05 so it shows there is a significant correlation. Moreover the value of $r$ count is bigger than the value of $r$ table, $0.766>0.4772$. it also shows that the significant correlation between two variables is exist. The research finds that there is a strong negative correlation among the students' speaking performance and speaking anxiety. It can be seen from the coefficient correlation of the research. The coefficient correlation is -0.766 . The negative value shows the negative correlation of two variables. While the value of 0.766 shows the strong correlation because it is more than 0.5 . In sum, the students' speaking performance and their speaking anxiety are strongly negative correlated.

When the significant correlation is exists among two variables it means one variable is affecting the other. In this case it can be seen that the speaking anxiety is affecting the students' speaking performance. The correlation is negative correlation so it simply can be said that the more anxious someone the worst speaking score they get. This finding is in line with Horwitz (2001) which says that the anxiety makes the students have a difficulties in language learning, including self-presentation and another language practices. It can be accepted that the more students afraid the more errors they produce and make their performance to be the bad one.

There are various specific causes make the students' having bad speaking performance. Those causes such as low proficiency, afraid of negative feedbacks whether from teacher of their friends and low motivation to learn (Liu \& Tarnopolsky, 2019; Tsiplakides, 2009; Yahya, 2013). Low proficiency on speaking skill of course makes the students difficult to show a performance well because they are not able to deliver the message in a proper language. Afraid of negative feedbacks usually prevents the students to perform in their best condition. They are afraid that they will receive negative feedbacks caused by errors they made. Also, receive negative feedback means receive low score, this actually make them afraid. While the worst is low motivation, it will lead them into low proficiency because they do not want to learn the skills and then they will be afraid to receive negative feedbacks when they perform. Those reasons come together and make the students are having speaking anxiety. Students are usually being anxious when they face some conditions, as Young (1990) said that speaking skill lesson is a lesson which produce the student's anxiety the most especially if it is on the spot.It can be seen from the daily activity of the students in the class which shows that they prefer to read and write rather than to speak. The lack of speaking practice is also become 
one of the cause and also the proof that the students are not prefer to speak. In sum, while studying english students usually feel anxious and of course it affects student in their study.

There is an explanation about how speaking anxiety influence speaking performance. According to Rector, n.d.(2005), anxiety occurs when someone is in a danger or a certain occasion which lead that person into an action to safe his/her life. In that occasion body will send signals to brain and the brain response the signal by producing adrenaline. The adrenaline gives alert feelings, energy and power to fight or avoid the danger. While at the same time, there are also negative effects of adrenaline such as nervous, tense, sweaty, trembling, and hard to breathe. Remember that anxiety affecting cognitive, physical and behavior, later Rector explain that in a test for example, anxiety affects cognitive by the thoughts that obligates someone to do the best, not failing test and doing no errors. It also affectingphysical by showing the symptom of strain and also behavioral, that is avoid studying or studying much material fast or in a short time in the end. Anxiety is a response of a body when it is obligated to do the best, whether when it is in an important event which is meaningful for his life (job interview or test for example) or even to make himself safe. Related to this research, in a speaking test, the adrenaline makes the students always looking for the best result, because it is important for them to proof their ability and to get the best score without doing any mistakes. On the other hand, some students are not mastering all of speaking aspects well. The expectation to get the best score is not linier with their speaking aspects mastery. Adrenaline is also lead students into strain which is affecting on their body language which will be not natural and awkward. The last effect, behavior, they may be decided to stop studying or study too hard in the end. These make their performance on speaking are just not natural and maximum. In sum speaking anxiety affecting speaking performance because the students are disturbed by their anxiety rather than focus on what should be done in a speaking test appropriately.

\section{CONCLUSION}

Anxiety is caused by several problems, such as low proficiency, afraid of negative feedbacks whether from teacher or their friends and low motivation to learn. These problems prevent them to get the best result on speaking test. Anxiety is also a response of the body for dangerous or important moments. Speaking test can be seen as important moments. As a response of the moment, the body produces adrenaline, the side effect of adrenaline trigger the anxiety which is affecting cognitive, physical and behavior. In general, the students are disrupted by those problems so that they can not achieve the best result on their speaking test. To decrease the speaking anxiety the students should be focus on how to improve their speaking skill rather than only focus on getting the best score. The thought of getting the best result only increase their anxiety and make it worst. Moreover, they may have more practices with their friend so they are more comfortable and confident to speak. When they are enjoying speaking skill learning they will find themself taking control of their speaking anxiety. The teacher also should give more group activities so that the students may explore and develop their speaking skill in a comfortable condition. Those conclusions can be addressed for future research. It may focus on finding the proper way to decrease the students' speaking anxiety depends on the students' characteristics and the method to decrease their speaking 
anxiety.

\section{REFERENCES}

Adriana, R., Melendez, M., Griselda, G., Zavala, Q., \& Mendez, R. F. (2014). TEACHING SPEAKING STRATEGIES TO BEGINNERS. European Scientific Journal, 1(February), 548-554.

Alabsi, T. A. (2016). The Effectiveness of Role Play Strategy in Teaching Vocabulary. Theory and Practice in Language Studies, 6(2), 227-234.

Aliakbari, M. (2010). The Impact of ' Role Play ' on Fostering EFL Learners ' Speaking Ability: A Task-Based Approach Mohammad Aliakbari \& Behroz Jamalvandi. Journal of Pan-Pacific Association of Applied Linguistics, 14(1), 15-29.

Anderson, P. L., Zimand, E., Hodges, L. F., \& Rothbaum, B. O. (2005). Cognitive behavioral therapy for public-speaking anxiety using virtual reality for exposure. Depression and Anxiety, 22(3), 156-158.

https://doi.org/10.1002/da.20090

Bacon-shone, J. (2015). Introduction to Quantitative Research Methods (Issue February). Graduate School, The University of Hong Kong. https://doi.org/10.13140/2.1.4466.3040

Brown, H. D. (2004). Language Assesment : Principle and Classroom Practice. Longman.

Ça, S. (2015). Examining EFL students 'foreign language speaking anxiety: The case at a Turkish state university. 199, 648-656. https://doi.org/10.1016/j.sbspro.2015.07.594

Chou, M. H. (2018). Speaking Anxiety and Strategy Use for Learning English as a Foreign. TESOL QUATERLY, 52(3), 611-633. https://doi.org/10.1002/tesq.455

Creswell, J. W. (2009). Research Design : Qualitative, Quantitative, and Mixed Methods Approaches. In Sage (Third edit, Vol. 8). https://doi.org/10.1163/22118993-90000268

Efrizal, D. (2012). Improving Students' Speaking through Communicative Language Teaching Method at Mts Ja-alhaq, Sentot Ali Basa Islamic Boarding School of Bengkulu , Indonesia Dedi Efrizal State Institute of Islamic Studies ( IAIN ) Bengkulu, Indonesia Abstract A . Intro. International Journal of Humanities and Social Science, 2(20), 127-134.

Goberman, A. M., Hughes, S., \& Haydock, T. (2011). Acoustic characteristics of public speaking: Anxiety and practice effects. Speech Communication, 53(6), 867-876. https://doi.org/10.1016/j.specom.2011.02.005

Harmer, J. (2001). The Practice of English Language Teaching (pp. 1-365). Longman.

Horwitz, E. (2001). LANGUAGE ANXIETY AND ACHIEVEMENT. Annual Review of Applied Linguistics, 21(112), 112-128.

Leong, L., \& Ahmadi, S. M. (2017). An Analysis of Factors Influencing Learners ' English Speaking Skill. International Journal of Research in English Education, 2(1), 34-41. 
Liu, M., \& Tarnopolsky, O. (2019). Interactive effects of English-speaking anxiety and strategy use on oral English test performance of high- and lowproficient Chinese university EFL learners. Cogent Education, 5(1), 1-14. https://doi.org/10.1080/2331186X.2018.1562410

Mulyatiningsih, E. (2011). Terapan Riset (1st ed.). UNY Press.

Oradee, T. (2012). Developing Speaking Skills Using Three Communicative Activities ( Discussion, Problem-Solving , and Role- Playing ). 2(6), 533535. https://doi.org/10.7763/IJSSH.2012.V2.164

Rao, P. S. (2019). The importance of speaking skills in english classrooms. Alford Council of International English \& Literature Journal(ACIELJ), Vol 2(Issue 2).

Rector, Neil A; Bordeau, Danielle; Kitchen, K. M. L. J. (2005). Anxiety disorders An information guide Anxiety disorders An information guide (1st ed.). CAMH.

Richards, J. C. (2008). Teaching Listening and Speaking From Theory to Practice. Cambridge University Press.

Sreehari, P. (2012). Communicative Language Teaching: Possibilities and Problems. English Language Teaching, 5(12), 87-93. https://doi.org/10.5539/elt.v5n12p87

Tsiplakides, I. (2009). Helping Students Overcome Foreign Language Speaking Anxiety in the English Classroom: Theoretical Issues and Practical Recommendations. 2(November), 39-44.

Woodrow, L. (2015). Anxiety and Speaking English as a Second Language. RELC Journal, 37(December 2006), 309-328. https://doi.org/10.1177/0033688206071315

Yahya, M. (2013). Measuring Speaking Anxiety Among Speech Communication Course Students at The Arab American University of Jenin (AAUJ). European Social Sciences Research Journal, 1(3), 229-241.

Young, D. J. (1990). An Investigation of Students 'Perspectives on Anxiety and Speaking. Foreign Language Annals, 23, 539-553. 